\title{
Isolation, characterization and efficacy of lytic bacteriophages against pathogenic Escherichia coli from hospital liquid waste
}

\author{
RAHMAD LINGGA $^{1,2}$, SRI BUDIARTI $^{3, \boldsymbol{v}}$, IMAN RUSMANA ${ }^{3}$, ARIS TRI WAHYUDI ${ }^{3}$ \\ ${ }^{1}$ Doctoral Program of Microbiology, Department of Biology Faculty of Mathematics and Natural Sciences, Institut Pertanian Bogor. Jl. Agatis, Kampus \\ IPB Dramaga, Bogor 16680, West Java, Indonesia. \\ ${ }^{2}$ Department of Biology, Faculty of Agriculture, Fisheries and Biology, Universitas Bangka Belitung. Jl. Kampus Terpadu UBB, Balunijuk, Merawang, \\ Bangka, Bangka Belitung 33172, Indonesia. \\ ${ }^{3}$ Department of Biology, Faculty of Mathematics and Natural Sciences, Institut Pertanian Bogor. Jl. Agatis, Kampus IPB Dramaga, Bogor 16680, West \\ Java, Indonesia. Tel./fax.: +62-251-8622833, `email: s_budiarti@yahoo.com, linkgarahmad@gmail.com
}

Manuscript received: 31 March 2020. Revision accepted: 23 June 2020.

\begin{abstract}
Lingga R, Budiarti S, Rusmana I, Wahyu AT. 2020. Isolation, characterization and efficacy of lytic bacteriophages against pathogenic Escherichia coli from hospital liquid waste. Biodiversitas 21: 3234-3241. Escherichia coli is known as a pathogenic contaminant bacteria in hospital wastewater hazardous to humans and the environment. Concerns about the emergence of chlorine- and antibiotic-resistant bacteria increase the urgency to find an alternative strategy to control pathogenic bacteria in hospital wastewater. One of the alternatives is using lytic bacteriophage. This study aimed to isolate, characterize, and examine the efficacy of lytic bacteriophage against pathogenic Escherichia coli from hospital wastewater. It isolated, characterized (plaque morphology, host range, virion electron micrograph, and sensitivity to temperature, $\mathrm{pH}$, and chlorine treatments), and tested the efficacy of lytic bacteriophages in controlling pathogenic E. coli isolated from hospital wastewater. Five phages were successfully obtained, all of which had clear plaques (lytic phage character). Based on host range assay, most of the phages could lyse all tested $E$. coli strains but not for other species. Electron micrograph photography revealed that the phages belonged to Myoviridae. The phages showed stability in high temperature, broad-ranged $\mathrm{pH}$, and high concentrations of chlorine treatments. Assay on phages efficacy suggested that the phages are capable of significantly reducing the E. coli population both in sterilized and non-sterilized wastewater. The combination of phage treatment and chlorine was more effective than single phage treatment. The efficacy test revealed that phage application in wastewater had the best result seen from cocktail treatment and a combination of phage treatment and chlorine. These results suggested that the phage can be a potential candidate for disinfection purposes.
\end{abstract}

Keywords: Escherichia coli, lytic bacteriophage, hospital liquid waste, antibiotic-resistant

\section{INTRODUCTION}

Escherichia coli is a Gram-negative bacterial species belonging to the Enterobacteriaceae family. It is a nonspore-forming rod that may or may not be mobile (some rods are flagellated, and some are not). The organism is a facultative anaerobe and ferments simple sugars such as glucose to form lactic, acetic, and formic acids. E. coli is not only known as a commensal of the gastrointestinal tract of vertebrates, including humans (Tenaillon et al. 2010), but also an important zoonotic pathogen with different pathogenic properties. It is characterized by particular subsets of genes associated with the virulence that identify them into distinct groups or pathogroups (Van den Beld and Reubsaet 2012). E. coli is often found as the most common hospital waste contaminating group.

Moreover, numerous studies reported the existence of antibiotic-resistant $E$. coli in wastewater treatment plants (Aslan et al. 2018; Budiarti et al. 2018; Diwan et al. 2010). $\mathrm{Hu}$ et al. (2011) also reported an increase in the Gramnegative pathogens, especially those of the Enterobacteriaceae family, from hospital waste. Anastasi et al. (2012) reported that some groups of pathogenic E. coli survive in all stages of sewage treatment, including the disinfection stage. They found that $56 \%$ of environmental strains carry virulence-gene belonging to intestinal pathogenic E. coli (IPEC) and uropathogenic E. coli (UPEC) pathotypes identical to those found in the final effluent from the sewage treatment plant. The results suggested that $E$. coli strains surviving wastewater treatment processes could also survive in the environment (Anastasi et al. 2012).

On the other hand, there are concerns about the adverse effects of using chemical disinfectants on the environment. The reaction between chlorine and organohalogen compounds can release Trihalomethane compounds that are carcinogenic and mutagenic (Chowdhury 2012). Also, the higher the dose of the chlorine used, the higher the probability of the formation of Trihalomethane (Herawati and Yuntarso 2017).

Nowadays, a significant health issue associated with $E$. coli is its role in the emergence and spread of antimicrobial resistance (Skurnik et al. 2015). The spread is related to the development of specific clones that acquire resistance genes, mostly via mobile genetic elements (Woodford et al. 2011).

All the problems above were the driver to find alternative methods for treating pathogenic bacteria in the 
wastewater treatment plant. The application of lytic bacteriophage is an alternative strategy to combat pathogenic bacterial contamination. A bacteriophage is a virus with the ability to infect and kill its host bacteria. Because of its narrow-spectrum infection ability, the bacteriophage is unlikely to trigger resistance in untargeted bacterial strains ( $\mathrm{Gu}$ et al. 2012). Besides, unlike chemical therapeutic agents, phage resistance may also induce losses to bacteria because phage-resistant bacteria may become less virulent in case of mutations in surface virulence factors such as lipopolysaccharide (LPS) (León et al. 2015). The present study aimed to isolate, characterize, and test the efficacy of lytic bacteriophage in controlling pathogenic E. coli isolated from hospital wastewater. Furthermore, the results of this study are expected to serve as a reference on the potency of lytic bacteriophage in controlling pathogenic bacteria in hospital wastewater.

\section{MATERIALS AND METHODS}

\section{Bacterial strains and culture conditions.}

This study used a total of $10 \mathrm{E}$. coli isolates collected from hospital wastewater. The isolates were identified for their biochemical and hemolytic activities and tested for their chlorine and antibiotic susceptibility. The list of strains used in this study is presented in Table 2. The isolates were grown at $37^{\circ} \mathrm{C}$ in nutrient broth (NB; Oxoid), on nutrient agar (NA; Oxoid), or NA soft agar overlays (0.75\% agar).

\section{Phage isolation}

The phages were isolated based on the method in a previous study by Budiarti (2011). The samples were obtained from cattle farming sewage and Cisadane River near Bogor Agricultural University. A total of $20 \mathrm{ml}$ of centrifuged effluent was mixed with $20 \mathrm{ml}$ double-strength $\mathrm{NB}$ and $50 \mathrm{ml}$ of each $E$. coli strain that had exponentially grown. The solution was incubated at $37^{\circ} \mathrm{C}, 120 \mathrm{rpm}$, for $24 \mathrm{~h}$. Next, it was centrifuged (30 $\mathrm{min}, 6000 \mathrm{rpm}$ ), and the supernatant was filtered through a $0.22 \mathrm{~mm}$ cellulose acetate membrane (GE Healthcare). Spot assays were performed against bacterial lawns to check the presence of phages. Inhibition haloes were further purified using toothpicks or Pasteur pipettes and paper to isolate all of the different phages. The plaque picking was repeated until single-plaque morphology was observed. The diameters of each plaque of the isolated phages were measured and characterized.

\section{Phage quantification}

Bacteriophage suspensions were diluted serially in NB media. A total of $100 \mu \mathrm{l}$ desired dilution of phages was incubated with $100 \mu \mathrm{l}$ specific strain of $E$. coli at $37^{\circ} \mathrm{C}$ for 20 minutes to allow the bacteriophage particles to attach to the host bacterial cells. The suspension was added into a tube containing overlay medium and mixed thoroughly. The mixture was poured over an underlay plate. The plates were incubated at $37^{\circ} \mathrm{C}$ for $18-24 \mathrm{~h}$. The plaques were counted on plates. Only plates with $30-300$ plaques were considered acceptable. The titer of the original phage preparation was determined by following the formula: Phage concentration $(\mathrm{pfu} / \mathrm{ml})=$ Number of plaques $\times 10 \times$ reciprocals of counted dilution.

\section{Host range assay}

The phage host range was determined using the doubleagar-layer plating method, as described previously by Budiarti (2011). A total of $100 \mu \mathrm{L}$ cell culture of each strain in exponential-phase was added to produce bacterial lawns. The bacteriophage titer was adjusted to $10^{9} \mathrm{PFU} \mathrm{ml}$ ${ }^{1}$ on; its bacterial hosts and 10-fold dilution series were spotted on each bacterial lawn. After 24-h incubation at $37^{\circ} \mathrm{C}$, the results were observed and scored.

\section{Examination of bacteriophage morphology}

A phage stock solution $(5 \mu \mathrm{L})$ was dropped onto the grid for 30 seconds and dried up using filter paper. $2 \%$ uranyl acetate solution $(5 \mu \mathrm{L})$ was also dropped onto the grid for 1 minute and dried up using filter paper for 60 minutes. The grid was placed in a holder and left for perfect drying. The specimen was observed using a transmission electron microscope (TEM JEOL JEM-1010 model) at $80 \mathrm{kV}$, and phages were examined at 20.00080.000 times magnification.

\section{Sensitivity to temperature, $\mathrm{pH}$, and chlorine treatments}

Phage sensitivity to temperature, $\mathrm{pH}$, and chlorine treatments was examined following the same procedure by Rattanachaikunsopon and Phumkhachorn (2012). The page sensitivity to temperature was monitored by giving various temperature treatments, i.e., $40^{\circ} \mathrm{C}, 50^{\circ} \mathrm{C}, 60^{\circ} \mathrm{C}, 70^{\circ} \mathrm{C}$, $80^{\circ} \mathrm{C}, 90^{\circ} \mathrm{C}$, and $100^{\circ} \mathrm{C}$. A total of $100 \mu 10^{6} \mathrm{PFU} / \mathrm{ml}$ phage liquid stock was added into $900 \mu \mathrm{l}$ SM buffer then placed in a microtube. The temperature treatment was carried out for 30 minutes. After heating at the assigned temperatures, the solutions were placed in an ice bath. Surviving a bacteriophage titer was assayed using the double-layer method.

Meanwhile, $\mathrm{pH}$ treatment was carried out using the SM buffer ranging between 1 to 12 . The phage sensitivity was also examined using 1, 10, 100, 500, 5,000, and 50,000 ppm chlorine. A total of $100 \mu 10^{6} \mathrm{PFU} / \mathrm{ml}$ phage liquid stock was added into $900 \mu \mathrm{l}$ SM buffer at various levels of $\mathrm{pH}$ and chlorine. The stock was incubated for 24 hours at $37^{\circ} \mathrm{C}$.

\section{Invitro phage efficacy assay}

A phage efficacy assay was conducted using a single phage for various bacterial hosts. A total of $100 \mu \mathrm{l} 24-\mathrm{h}$ culture of $E$. coli in OD 1 was infected by $100 \mu l$ phage stock (titer $10^{8}$ ). The plating was conducted during various incubation times, i.e., respectively $0,2,4,8,12,16,18,20$, and 24 hours of incubation.

\section{Phage efficacy in hospital wastewater}

The efficacy of phage application into hospital wastewater was examined by introducing phage stock and bacteria into the sterilized wastewater. A total of $100 \mu 124-$ h culture of E. coli in OD 1 was infected by $100 \mu$ phage 
stock (titer $10^{8}$ ). The plating was conducted during various incubation times, i.e., respectively $0,4,8,12,16,20$, and 24 hours of incubation.

\section{Efficacy of phage-chlorine combination}

The efficacy of the application of phage-chlorine combination into hospital wastewater was examined by introducing phage stock-chlorine combination (in various titer concentrations) and bacteria into the sterilized and non-sterilized wastewater. A total of $100 \mu \mathrm{l} 24$-h culture of $E$. coli in OD 1 was infected by $100 \mu \mathrm{l}$ phage stockchlorine combination for sterilized wastewater treatment. For the non-sterilized wastewater treatment, $1 \%$ of the total mixing volume of the phage stock-chlorine combination was added. The plating was conducted during various incubation times, i.e., respectively $0,2,4,6,8$, and 12 hours of incubation.

\section{RESULTS AND DISCUSSION}

\section{Bacteriophage isolation}

A bacteriophage was isolated from various sources (household waste, river, chicken farm waste, and slaughterhouse waste). A total of ten isolates of $E$. coli were used in this procedure. Plaque formation on the bacterial lawn indicated the presence of phage. A total of five phages were successfully obtained, all of which were lytic phages, as characterized by the presence of clear plaques on the bacterial lawns (Figure 1). Phages were named after their bacterial-host codes, i.e., FE1A, FE1B, FE1C, FK7A, FI21. See Table 1 for the plaque characteristics. The plaque formations were observable due to the inhibition of growth and lyses of the phage-infected cells on the bacterial lawn. They were distinguished into clear and turbid plaques. They also varied in their diameters.

\section{Bacteriophage host range}

The specificity of bacteriophage against various bacteria was examined using the spot test method. All of the tested $E$. coli isolates were susceptible to the phages. Phages FE1A, FE1B, FE1C, and FK7A were able to lyse all tested E. coli. Meanwhile, only phage FI21 was unable to lyse E. coli isolate E1 (Table 2). Among ten E. coli isolates used as phage hosts in this test, there were different patterns of antibiotic resistance. All of $E$. coli isolates were resistant to Clyndamicine and Rifampicin. Meanwhile, only isolates $\mathrm{K} 7, \mathrm{I} 2, \mathrm{I} 18,126$, and $\mathrm{K} 11$ were resistant to Amoxicillin. Isolates K7, I2, I18, 126 also showed resistance to Trimethoprim-Sulfamethoxazole. All isolates were sensitive to chloramphenicol and levofloxacin (Data not shown).

All 6 phages were unable to lyse non-E. coli hosts such as Bacillus pumilus, Citrobacter freundii, Photobacterium damseilae, Salmonella sp., and Proteus mirabilis.

\section{Bacteriophage virion morphology}

Morphological characteristics of bacteriophages were examined using transmission electron microscopy. Phage FK7A appeared to have a hexagonal head $(54.16 \pm 1.54 \mathrm{~nm}$ in diameter) with a contractile tail of $100.42 \pm 1.38 \mathrm{~nm}$ long and $7.74 \pm 2.5 \mathrm{~nm}$ wide. A tail knob was observed $(20.03 \pm 3.66)$ as well as a base plate. However, there was no collar nor tail appendage observed (Figure 2).

\section{Sensitivity to temperature, $\mathrm{pH}$, and chlorine treatments}

A sensitivity tests to various temperature, $\mathrm{pH}$, and chlorine were conducted to test the stability of phages to physical and chemical factors. The sensitivity of the isolated phages to temperature was examined by calculating the PFU/ml of the plaque counts after treating with various temperatures for 30 minutes. The results of the temperature sensitivity test showed that some phages titer significantly reduced at $90^{\circ} \mathrm{C}$ and $100^{\circ} \mathrm{C}$. The lowest titer reduction at $90^{\circ} \mathrm{C}$ and $100^{\circ} \mathrm{C}$ was found in phages $\mathrm{FE} 1 \mathrm{~A}$ and FE1B. Meanwhile, phage FI21 was activated at $90^{\circ} \mathrm{C}$, and phage $\mathrm{FE} 1 \mathrm{C}$ was activated at $100^{\circ} \mathrm{C}$. All phage titers were slightly reduced at a lower temperature.

Table 2. Determination of the host range of the phages

\begin{tabular}{lccccc}
\hline Bacterial Testers & FE1 & FE1 & FE1 & FK7 & FI2 \\
& A & B & C & A & 1 \\
\hline E. coli isolate E1 & + & + & + & + & - \\
E. coli isolate K7 & + & + & + & + & + \\
E. coli isolate I21 & + & + & + & + & + \\
E. coli isolate E5 & + & + & + & + & + \\
E. coli isolate I2 & + & + & + & + & + \\
E. coli isolate E6 & + & + & + & + & + \\
E. coli isolate I18 & + & + & + & + & + \\
E. coli isolate I26 & + & + & + & + & + \\
E. coli isolate I5 & + & + & + & + & + \\
E. coli isolate K11 & + & + & + & + & + \\
Citrobacter freundii & - & - & - & - & - \\
Salmonella sp. & - & - & - & - & - \\
Bacillus pumilus & - & - & - & - & - \\
Proteus mirabilis & - & - & - & - & - \\
Photobacterium & - & - & - & - & - \\
damselae & - & - & - & & \\
\hline
\end{tabular}

Table 1. Phages' characteristics

\begin{tabular}{|c|c|c|c|}
\hline Phages & Morphology of plaque & $\begin{array}{l}\text { Diameter of } \\
\text { plaque }(\mathrm{mm})\end{array}$ & $\begin{array}{c}\text { Phage titer } \\
\left(\mathrm{pfu} / \mathrm{ml}^{-1}\right)\end{array}$ \\
\hline FE1A & Clear plaque, regular-shaped & $4.67 \pm 0.32$ & $6.3 \times 10^{7}$ \\
\hline FE1B & Clear plaque, regular-shaped & $3.13 \pm 0.21$ & $4.0 \times 10^{7}$ \\
\hline FE1C & Clear plaque, regular shaped, with halo zone at the center of the plaque & $3.23 \pm 0.55$ & $8.6 \times 10^{7}$ \\
\hline FK7A & Clear plaque, irregular shaped & $2.77 \pm 0.25$ & $1.6 \times 10^{7}$ \\
\hline FI21 & Clear plaque, irregular shaped & $1.47 \pm 0.15$ & $1.4 \times 10^{7}$ \\
\hline
\end{tabular}




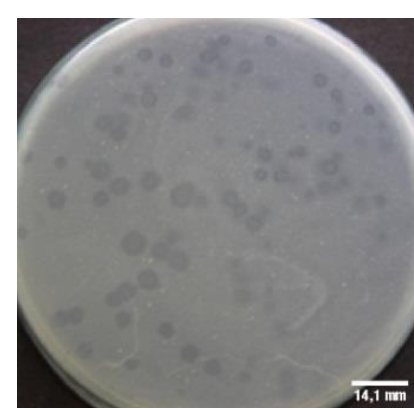

A

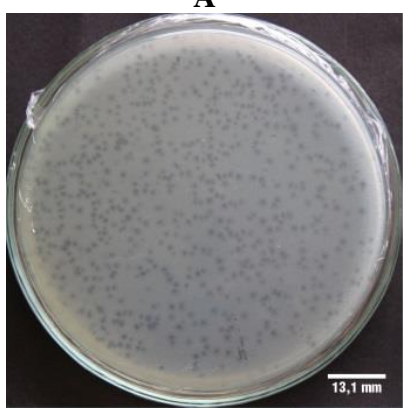

D

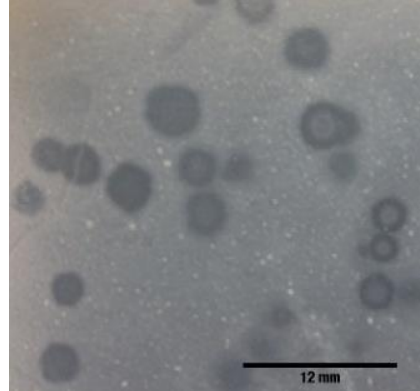

B

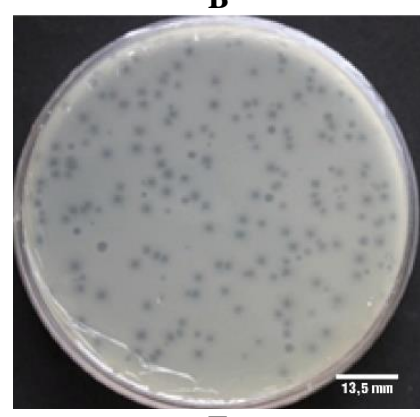

$\mathbf{E}$

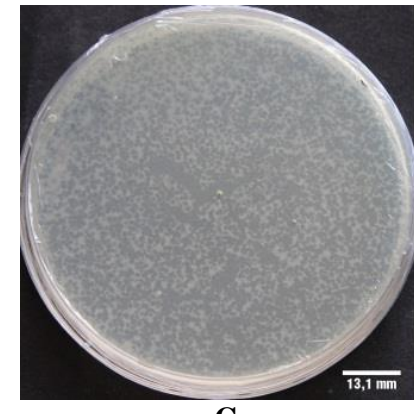

C

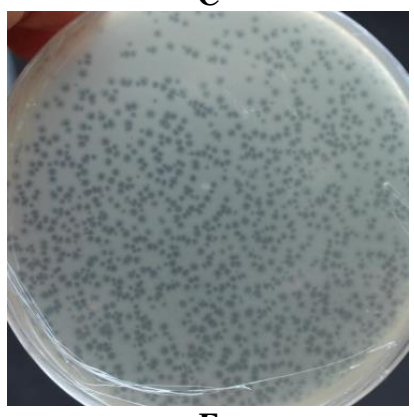

Figure 1. Plaque morphology.0 A. Plaques during isolation, B. Characteristics of 3 different plaques (FE1A, FE1B, FE1C), C. Purified plaque (FE1A), D. Purified plaque (FE1B), E. Purified plaque (FI21), F. Purified plaque (FK7A)

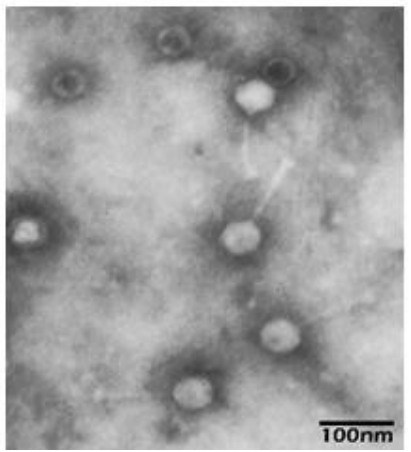

A

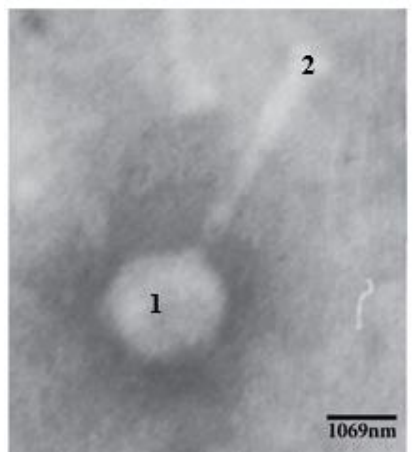

B
Figure 2. Phage FK7A Micrograph morphology.A. Virions of phage FK7A, B. 1. Hexagonal shaped head; 2. Tail knob).

In terms of stability to various $\mathrm{pH}$, all phages were inactive at $\mathrm{pH} 1$. Only phage FI21 was inactive at $\mathrm{pH}$ 2. On the other hand, all the phage titers significantly decreased at $\mathrm{pH} 12$, and phage FI21 was activated. All the phages' activities were most stable at $\mathrm{pH} 7$ and $\mathrm{pH}$ 8. The present study also found that all phages were stable at low chlorine concentration. Phages FE1A, FE1B, FE1C, and FK7A remained active in all chlorine concentrations $(50,000 \mathrm{ppm}$, $5,000 \mathrm{ppm}$, and $500 \mathrm{ppm}$ ). Only phage FI21 was inactive in 50,000 ppm chlorine.

\section{Bacteriophage efficacy in bacterial control}

A phage bacteriolytic efficacy test was conducted in vitro and wastewater treatment. For the in vitro test, all treatments were added with $10^{5} \mathrm{CFU} / \mathrm{ml}$ bacterial-host and $10^{6} \mathrm{PFU} / \mathrm{ml}$ phage to gained MOI $10^{1}$. The populations of the bacterial host were counted following the Total Plate Count Method. See Figure 4 for the counting result. In this test, there was no bacterial population increase in treatment 0 to 4 hours of incubation (on the contrary, control without phage showed a constant rise in its bacterial population). After 8 to 24 hours, the bacterial population gradually increased. However, the increase was significantly different from (lower than) the control, presumably because of the number of applied phages in the treatment. In wastewater treatment, in general, all the treatments showed an increase in the population of $E$. coli at the initial hour until the $4^{\text {th }}$ incubation time. Next, the bacterial population was seen to decrease during the phage treatment (on the contrary from the control) (Figure 5). This decrease suggested the activity of the phages that were capable of lysing bacterial cells in wastewater.

\section{Bacteriophage-chlorine efficacy in wastewater}

In the efficacy test on the phage-chlorine combination (both in sterile and non-sterile wastewater), a different population decline was observed between high and low chlorine concentrations (Figures 6 and 7). Moreover, in the treatment with chlorine concentrations of $50,000 \mathrm{ppm}$ and $10,000 \mathrm{ppm}$, no bacterial population was observed in the wastewater (data not shown) because high chlorine concentration is capable of eliminating all bacterial populations in sewage. There was a significant difference in the population declines at the beginning of the treatment, wherein the sterile wastewater treatment the drop was faster than that in non-sterile one. The difference was correlated with the fact that non-sterile wastewater had higher bacterial density and diversity than the sterile one. 


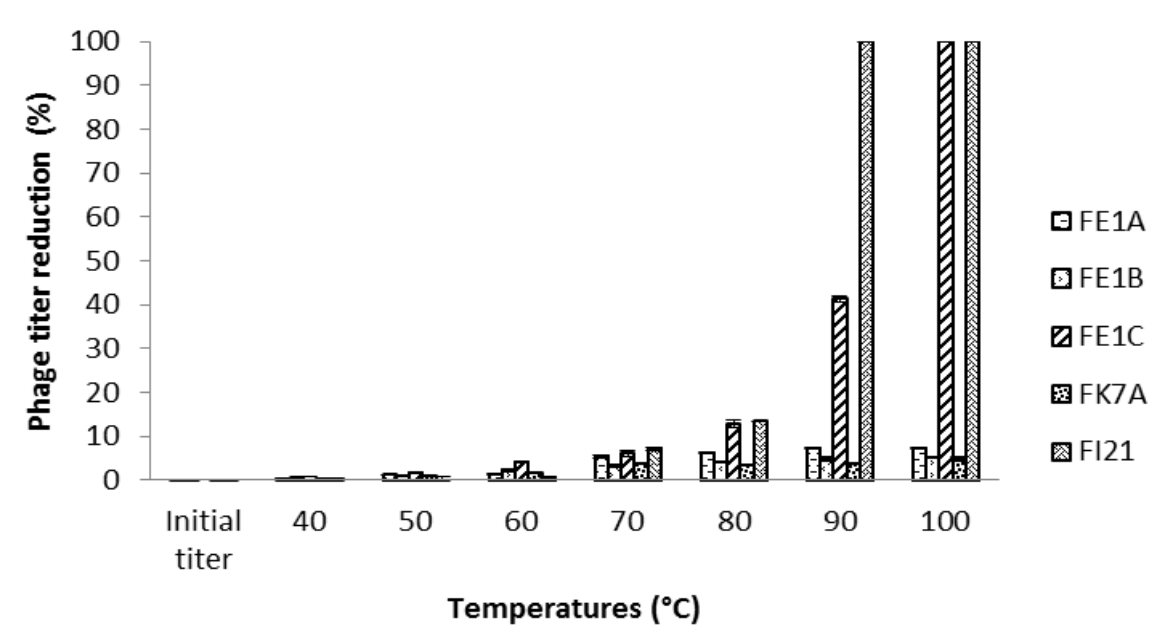

Figure 3. Phage titer decreasing after treated at various temperature for 30 minutes

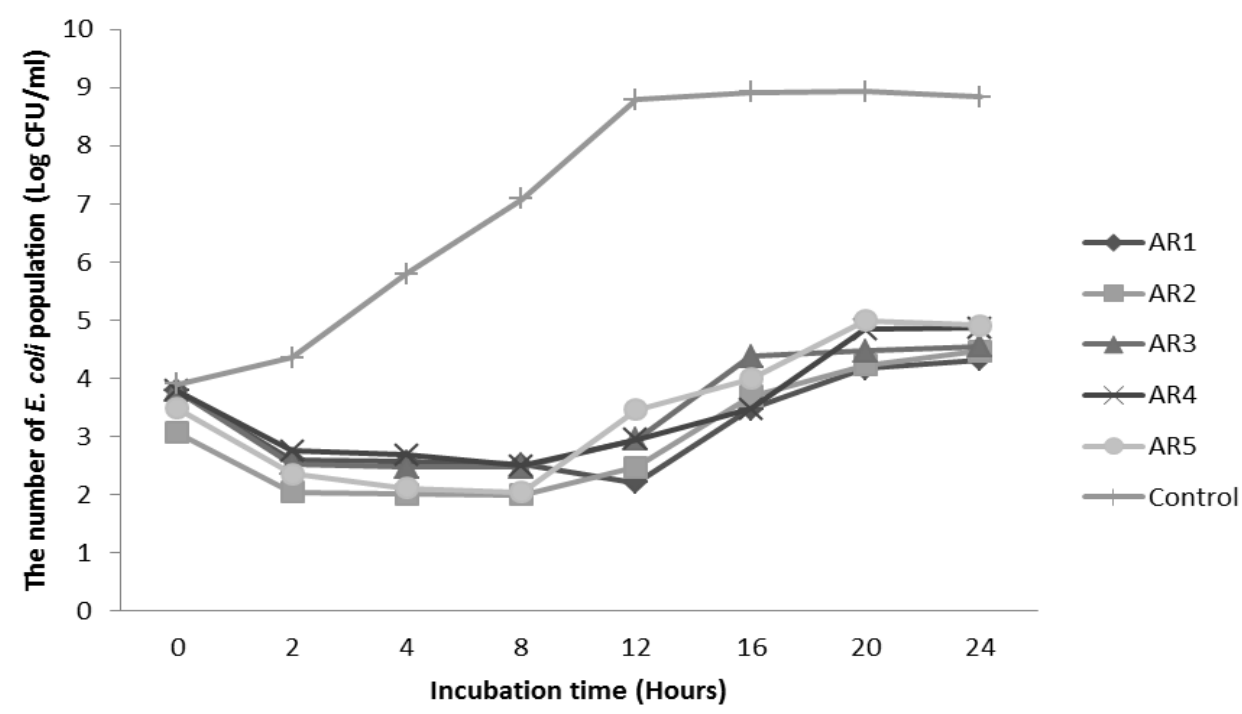

Figure 4. The efficacy of phages in vitro to control E. coli (AR1: E. coli E1 and phage FE1A; AR2: E. coli K7 and phage FK7A; AR3: E. coli $\mathrm{E} 1$ and phage FE1B; AR4: E. coli $\mathrm{E} 1$ and phage FE1C; AR5: E. coli 21 and phage FI21).

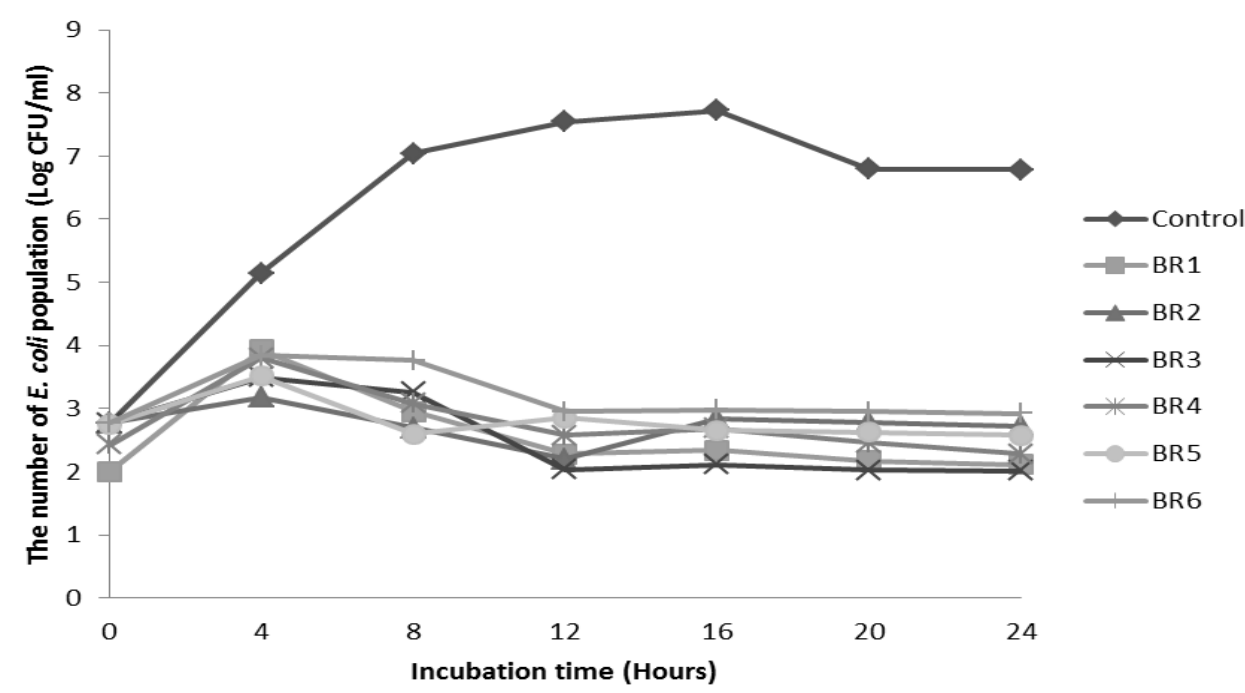

Figure 5. The efficacy of phages in hospital wastewater to control E. coli (BR1: E. coli K7 and phage FE1A, FK7A, FE1C; BR2: E. coli 121 and phage FE1A, FK7A, FI21; BR3: E. coli E1 and phage FE1A, FK7A, FE1C; BR4: E. coli K7 and phage FK7A; BR5: E. coli E1 and phage FE1A, BR6: E. coli E1, K7, I21, and phage FE1A). 


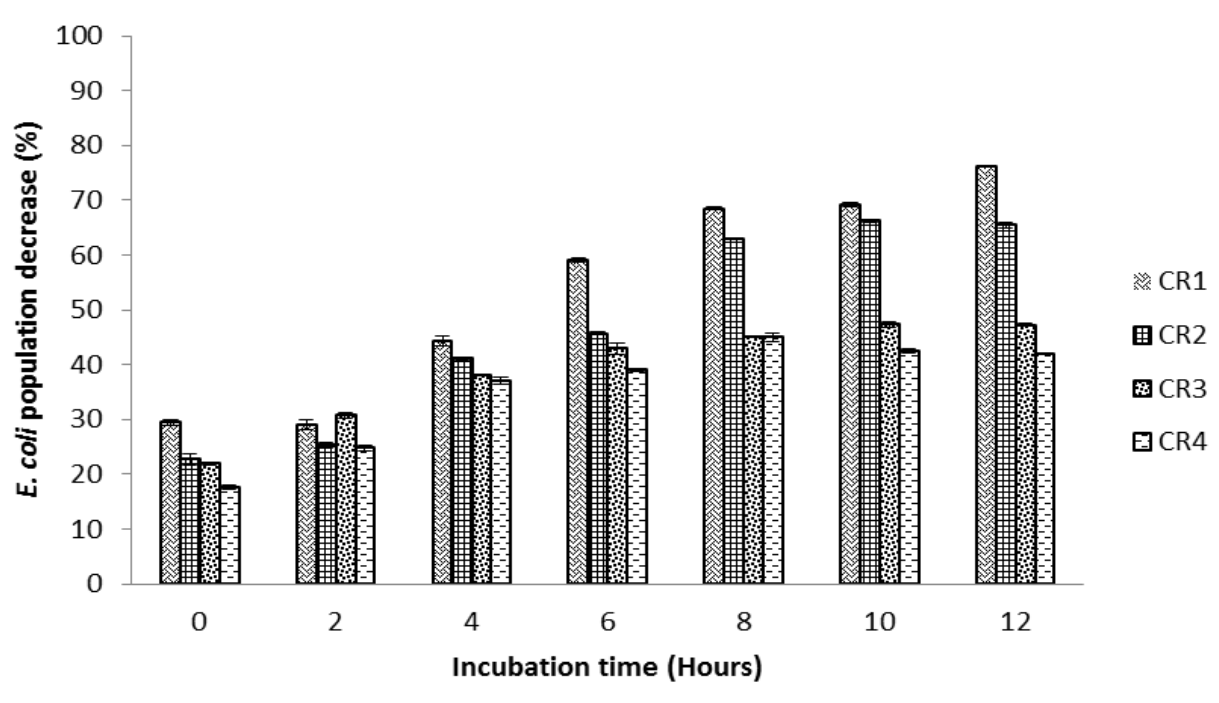

Figure 6. The efficacy of phage-chlorine combination to control E. coli in sterilized wastewater (CR1: E. coli K7 and phage FK7A combined with $1000 \mathrm{ppm}$ chlorine; CR2: E. coli K7 and phage FK7A combined with 100 ppm chlorine; CR3: E. coli K7 and phage FK7A combined with 10 ppm chlorine; CR4: E. coli K7 and phage FK7A combined with 1 ppm chlorine).

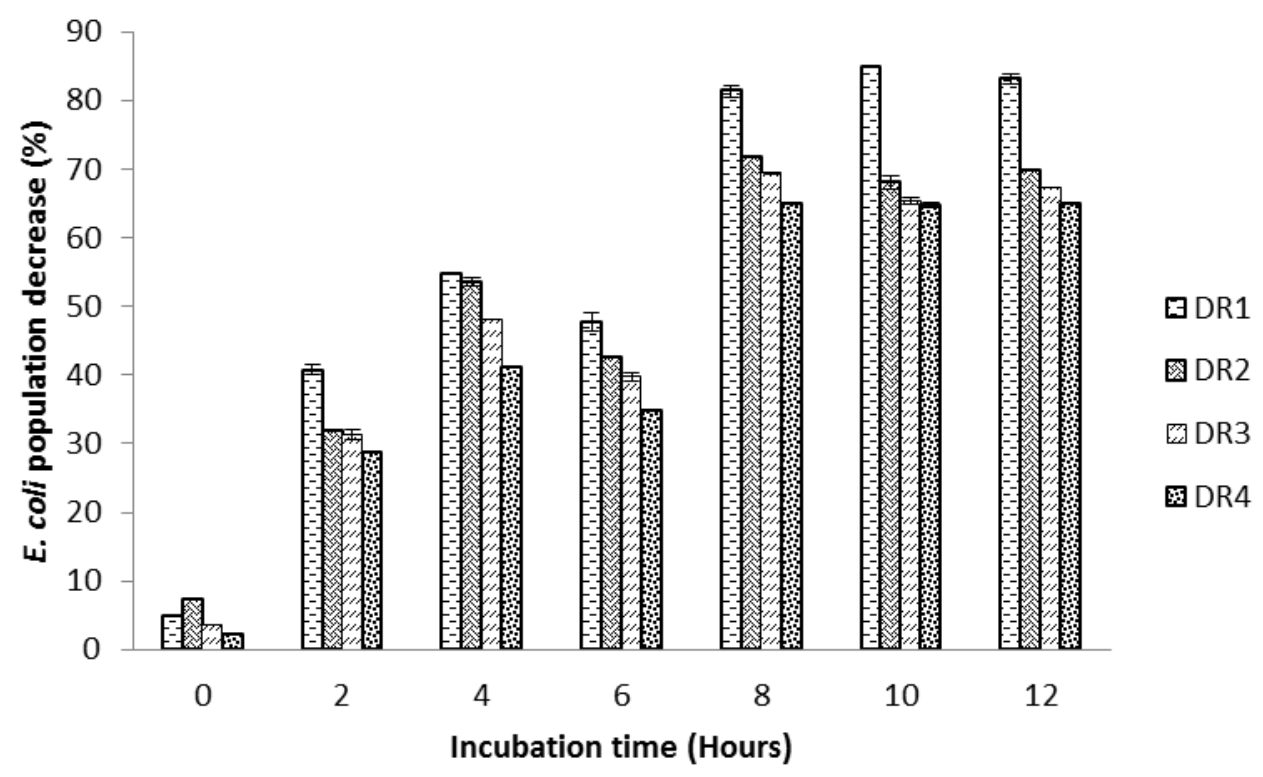

Figure 7. The efficacy of phage-chlorine combination to control E. coli in non-sterilized wastewater (DR1: a combination of phage FK7A-1000 ppm chlorine; DR2: a combination of phage FK7A-100 ppm chlorine; DR3: a combination of phage FK7A-10 ppm chlorine; DR4: a combination of phage FK7A-1 ppm chlorine)

\section{Discussions}

In this study, it was observed that all the phages varied in size and shape of plaques. The plaque sizes were affected by several factors, including adsorption rates, lysis time, virion morphology, and diffusion abilities. The adsorption rate negatively affected the plaque size. It was a function of the phage diffusion coefficient, which is a function of medium viscosity and the size of phage virion. The larger the virion size is, the smaller the diameter of the plaque will be. Long phage lysis time will increase the size of the plaque (although at a specific time, the lysis will decrease the plaque size). This result is because longer progeny formation time will reduce the time for phage particles to diffuse between host cells. Short lysis time and lower number of progenies will lead to a smaller plaque size (Gallet et al. 2011). The phages that were successfully isolated appeared to have virulent characteristics or a lytic life cycle, as shown by the clear plaques. Lytic phages are highly appropriate to control bacterial contamination because they will immediately kill their hosts without possibly forming lysogen in the infected cell population (Fernández et al. 2019). Phage is also known only to infect and proliferate in a suitable host cell (Budiarti et al. 2019). In this study, it was observed that all phages were specifically infected and lysed E. coli strains but not for other bacteria. The study revealed that two phages could 
not lyse all tested E. coli strains. Lu and Breidt (2015) reported that $\$ 241$ phage, a specific E. coli O157: H7 phage, just only infect strains that have $\mathrm{O} 157$ antigen, and $E$. coli strains to lack $\mathrm{O} 157$ antigen were resistant to the phage infection, regardless of the presence or absence of $\mathrm{H} 7$ antigen. In terms of virion trait, the electron micrograph indicated that the virions of the phages belonged to Myoviridae of the Caudovirales order. Ackermann (2009) classified phage with a tail surrounded by sheat into Myoviridae. Family of Myoviridae are virulent phage, so that not integrated their genetic material to the host (lysogeny cycle) but kills the host immediately (lytic cycle) (Suttle 2005). All of these are essential requirements in the use of phage to control pathogenic bacteria.

Temperature plays an essential role in the stability of phage protein (Budiarti et al. 2019). They found that Salmonella-phages are stable at $27^{\circ} \mathrm{C}$ to $30^{\circ} \mathrm{C}$ for 30 minutes incubation and become unstable at $45^{\circ} \mathrm{C}, 55^{\circ} \mathrm{C}$, and $60^{\circ} \mathrm{C}$. Rattanachaikunsopon and Phumkhachorn (2012) also reported that phages would generally be inactive at $80^{\circ} \mathrm{C}$. Furthermore, Basdew and Laing (2014) stated that high-temperature treatment could reduce phage activity. Atamer et al. (2010) reported that electron microscopic analysis of Lactococcal phage revealed that thermal treatments cause morphological changes on phage particles. Nevertheless, their findings also suggested that heat resistance of phage P680 (heat-resistant Lactococcal Phage) is based on both the increased stability of phage DNA packaged in the phage capsids and enhanced stability of phage particles. This mechanism presumably was what happened during the examination of the unusual phage stability to high temperature in this study.

It is crucial to examine the effect of different $\mathrm{pH}$ on the viability of the isolated phages to be able to handle the preservation, usage, and application of the phage correctly throughout phage treatment. The effect of $\mathrm{pH}$ on reducing phage activity was through the inhibition of the attachment process, formation of the particle aggregates, and attachment of the phage particles to media or phage packaging (Taj et al. 2014). Phage stability at different $\mathrm{pH}$ was also determined by chemical composition in the buffer. In this study, sodium magnesium buffer was used (SM buffer). Budiarti et al. 2019 found that phage had the best stability in SM buffer at $27^{\circ} \mathrm{C}$ or $4^{\circ} \mathrm{C}$.

Meanwhile, the present study revealed that the stability of phages to various concentrations of chlorine is useful information for phage application in wastewater treatment containing chlorine. Kanna (2015) reported that phage is more resistant to free chlorine than any other group of viruses. Besides, Zhong et al. (2017) suggested that viruses can develop resistance mechanisms against disinfectants that target proteins and nucleic acids.

The results of this study suggested that phage treatment both in sterile and non-sterile wastewater is capable of reducing the bacterial population. The most significant result was the phages that were stable when combined with chlorine. These results could become one of the alternatives to control pathogenic bacteria in wastewater, i.e., by combining the two treatments. By doing so, the efficacy of phage treatment can be improved as long as numerous constraints about the number of applied phage titers and application time are identified. Periasamy and Sundaram (2013) claimed that as the time of the incubation increase, the host population in lactose and sewage water samples would also increase. In contrast, in other treatments, the increase was not that significant. In this study, while the target population increased in phage treatment samples, the increase was not that high, presumably due to the adsorption of the phage particles that might change the metabolic rate of the target pathogens. In un-inoculated treatment, there was a steady increase in the target population, indicating that the phages reduced the number of the target population. The ratio between phages and the number of bacterial target populations also influenced the results. To control the bacterial population, applying more phages will generate a better result. Also, the minimum phage concentration required to achieve antibacterial efficacy changes when the bacterial cell concentration is different, while the phage input concentration is constant (Abedon 2016). The potential application of the phage-chlorine combination in controlling pathogenic bacteria in liquid waste will be enormous because of the concern about bacterial resistance to the chlorine disinfection process in the sewage treatment plant. As reported by $\mathrm{Se}^{\prime} \mathrm{ka}$ et al. (2001), bacterial resistance to chlorine in sewage treatment can cause disinfection failure (for example, chlorine-resistant $021 \mathrm{~N}$ isolates).

In conclusion, a total of five phages were obtained from cattle farming sewage and Cisadane River in Bogor. The host range test showed that all phages were capable of lysing tested $E$. coli host only. The electron micrograph indicated that the virions of the phages belonged to Myoviridae. Phages were stable in heat, $\mathrm{pH}$, and chlorine treatments and were effective in reducing bacterial growth, both in vitro and in wastewater. Their capability in lysing the bacterial host was the same when combined with chlorine, both in sterile and non-sterile wastewater.

\section{ACKNOWLEDGEMENTS}

We declare that there is no competing interest. This work was funded by the Indonesia Endowment Fund for Education (LPDP).

\section{REFERENCES}

Abedon ST. 2016. Phage therapy dosing: The problem (s) with multiplicity of infection (MOI). Bacteriophage 6 (3): e1220348. DOI: 10.1080/21597081.2016. 1220348.

Ackermann HW. 2009. Phage classification and characterization. In: Clokie MR, Kropinski Am (eds.). Bacteriophages methods and protocols. Vol. 501. Humana Press, New York.

Anastasi EM, Matthews B, Stratton HM, Katouli M. 2012. Pathogenic Escherichia coli found in sewage treatment plants and environmental waters. Appl Environ Microbiol 78 (6): 5536-5541.

Atamer Z, Dietrich J, Neve H, Heller KJ, Hinrichs J. 2010. Influence of the suspension media on the thermal treatment of mesophilic lactococcal bacteriophages. Intl Dairy J 20: 408-414. 
Aslan A, Cole Z, Bhattacharya A, Oyibo O. 2018. Presence of Antibioticresistant Escherichia coli in wastewater treatment plant effluents utilized as water reuse for irrigation. Water 805 (10): 1-11.

Basdew IH, Laing MD. 2014. Stress sensitivity assays of bacteriophages associated with Staphylococcus aureus, causal organism of bovine mastitis. Afr J Microbiol Res 8 (2): 200-210.

Budiarti S, Pratiwi RH, Rusmana I. 2011. Infectivity of lytic phage to Enteropathogenic Escherichia coli from diarrheal patients in Indonesia. J US-China Med Sci 8 (5): 273-282.

Budiarti S, Lingga R, Rusmana I, Wahyudi AT. 2018. Antibiotics resistant Escherichia coli from hospital liquid waste. J Appl Biol Sci 21 (1): 36-40.

Budiarti S, Sunarti RN, Listya SAP, Rusmana I. 2019. Biological characteristics and lytic effectiveness of phages isolated from domestic wastewater against indigenous Salmonella spp. J Environ Biol 40: 53-60.

Chowdhury S. 2012. Heterotrophic bacteria in drinking water distribution system review. Environ Monit Assess 184: 6087-6137.

Diwan V, Tamhankar AJ, Khandal RK. 2010. Antibiotics and antibioticresistant bacteria in waters associated with hospital in Ujjain, India BMC Public Health 10: 414. DOI: 10.1186/1471-2458-10-414.

Fernández L, Gutiérrez D, García P, Rodríguez A. 2019. The perfect bacteriophage for therapeutic applications - a quick guide. Antibiotics 8: 126. DOI: 10.3390/antibiotics8030126.

Gallet R, Kannoly S, Wang I. 2011. Effects of bacteriophage traits on plaque formation. BMC Microbiol 11 (181): 1-16. DOI: 10.1186/1471-2180-11-181.

Gu J, Liu X, Li Y, Han W, Lei L, Yang Y, Zhao H, Gao Y, Song J, Lu R, Sun C, Feng X. 2012. A method for generation phage cocktail with great therapeutic potential. PLoS One 7 (3): e31698. DOI 10.1371/journal.pone.0031698.

Herawati D, Yuntarso A. 2017. Penentuan dosis kaporit sebagai desinfektan dalam menyisihkan konsentrasi ammonium pada air kolam renang. J Sain Health 1 (2): 13-22.

Hu F, Chen S, Xu X, Gou Y, Liu Y, Zhu D, Zhang Y. 2011. Emergence of Carbapenem-resistant clinical Enterobacteriaceae isolates from a teaching hospital in Shanghai, China. J Med Microbiol 61: 132-136.

Kanna RJ. 2015. Inactivation of Viruses in Water by Chlorination using Bacteriophages as Model Organisms. [Thesis]. Swedish University of Agricultural Sciences, Uppsala, Sweden.
León M, Bastías R. 2015. Virulence reduction in bacteriophage resistant bacteria. Front Microbiol 6: 343. DOI: 10.3389/fmicb.2015.00343.

Lu Z, Breidt F. 2015. Escherichia coli O157: H7 bacteriophage 241 isolated from an industrial cucumber fermentation at high acidity and salinity. Front Microbiol 6: 1-10. DOI: 10.3389/fmicb.2015.00067.

Rattanachaikunsopon P, Phumkhachorn P. 2012. Bacteriophage PPST1 isolated from hospital wastewater, a potential therapeutic agent against drug resistant Salmonella enterica subsp. enterica serovar Typhi. Intechopen, London. DOI: 10.5772/30446.

$\mathrm{Se}^{\prime}$ ka MA, Kalogo Y, Hammes F, Kielemoes J, Verstraete W. 2001. Chlorine-susceptible and chlorine-resistant type $021 \mathrm{~N}$ bacteria occurring in bulking activated sludges. Appl Environ Microbiol 67: 5303-5307.

Skurnik D, Clermont O, Guillard T, Launay A, Danilchanka O, Pons S, Diancourt L, Lebreton F, Kadlec K, Roux D, Jiang D, Dion S, Aschard H, Denamur M, Cywes-Bentley C, Schwarz S, Tenaillon O, Andremont A, Picard B, Mekalanos J, Brisse S, Denamur E. 2015. Emergence of antimicrobial-resistant Escherichia coli of animal origin spreading in humans. Mol Biol Evol 33 (4): 898-914.

Suttle CA. 2005.Viruses in the sea. Nature 437: 356-361.

Taj MK, Ling JX, Bing LL, Qi Z, Taj I, Hassani TM, Samreen Z, Yunlin W. 2014. Effect of dilution, temperature and ph on the lysis activity of T4 phage against E. coli BL21. J Animal Plant Sci 24 (4): 12521255

Tenaillon O, Skurnik D, Picard B, Denamur E. 2010. The population genetics of commensal Escherichia coli. Nat Rev Microbiol 8: 207217.

Van den Beld MJ, Reubsaet FA. 2012. Differentiation between Shigella, Enteroinvasive Escherichia coli (EIEC) and noninvasive Escherichia coli. Eur J Clin Microbiol Infect Dis 31: 899-904.

Woodford N, Turton JF, Livermore DM. 2011. Multiresistant Gramnegative bacteria: the role of high-risk clones in the dissemination of antibiotic resistance. FEMS Microbiol Rev 35: 736755.

Zhong Q, Carratalà A, Ossola R, Bachmann V, Kohn T. 2017. Crossresistance of uv- or chlorine dioxide-resistant echovirus 11 to other disinfectants. Front Microbiol 8: 1-12. DOI: 10.3389/fmicb.2017.01928. 